International Journal of Health Science and Technology, 3 (1), 2021, 130-137

\title{
The effect of core stability exercise in reducing the risk of falling in the elderly at the work area of Kasian 1 public health center
}

\author{
Veni Fatmawati $^{1 *}$, Nova Mega Rukmana², Wibowo Septianto ${ }^{3}$, Diyas Elsa Yuniarsih ${ }^{4}$ \\ ${ }^{1.4}$ Universitas 'Aisyiyah Yogyakarta \\ ${ }^{2}$ Mitra Indonesia University \\ ${ }^{3}$ Kasian 1 Public Health Center \\ ${ }^{1}$ venifatma10@gmail.com*, ${ }^{2}$ novamegarukmana56@gmail.com, ${ }^{3}$ wibowoseptianto83@gmail.com, \\ ${ }^{4}$ diyaselsay@gmail.com \\ * corresponding author
}

Submission date: 18 Februari 2021, Receiptdate: 14 April 2021, Publicationdate: 1 Juli 2021

\begin{abstract}
Elderly is a condition that will be experienced by each people, where the age range is from 45 to 75 years. The process adds up age followed also by changes that occur in body systems either physiologically or pathologically in the presence of comorbidities. One of the processes that occurs is function cerebellum descends by starting with a balance disturbance and then the brain system, resulting in the risk of falling. Elderly experiencing falls can be affected by some things such as disorders of the brain system, self it self and the environment. A part from anatomical factors, there is also a lighting environment usually the elderly always wake up at night, if the environment is less lighting then the risk of falling is higher and if the condition of waking up, the concentration and muscle power cannot be optimal, resulting in decreased balance so that the risk of falling is higher. One way to maintain and minimize the risk can be done the core stability exercise. Benefits of core stability exercise is to strengthen the core as the support of the body so that the body can be stable. This type of research is experiment, using quasi experimental design with pre test and post test group design. The statistic test using Wilcoxon test. Sample of elderly at integrated healthcare center in Ngebel, totaled are 34 elderly. Elderly sample criteria age 60-74 years, do not use assistive devices and do not experience neurological disorders. Measure morse fall skale. The results of the homogeneity test show that the significance value (p) core stability exercise of 0.323 , because of the significance of $p>0.05$ it can be concluded that the population is from the same variant or homogeneous. The calculation of the data normality test used the Shapiro-Wilk Test and is said to be normal if p>0,05. Data normality test results 0.085 . Hypothesis Test with willcoxon test because it has a normal and homogeneous data distribution in the group. From the test results obtained with a value of $\mathrm{P}=0.034$, meaning $\mathrm{P}<0,05$, so that there is an effect of core stability training on the risk of falling in the elderly.
\end{abstract}

Keywords: elderly, core stability exercise, risk of falling

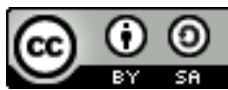




\section{INTRODUCTION}

According to WHO, middle age is the age group between 45-59 years, for the elderly (elderly) that is between the ages of 60 and 74 years, for the elderly (Old) that is between the ages of 75 and 90 years, and the very old (Very old) namely the age of 90 years (Munawwarah \& Nindya, 2015). The entire population aged $\geq 65$ that appear healthy in community, there are 35-40\% experience falls every year (Pranarka,2006).

The number of elderly people in Yogyakarta Province in 2019 according to the Central Agency for Statistics of the Special Region of Yogyakarta, namely 13 percent of the total population, namely 45.000 peoples. One of the factors that influence the risk of falling in the elderly is synergistic response of the postural muscles, namely the balance of the body in various positions will only be possible if the response of the postural muscles works synergistically as a reaction to changes in position, fulcrum, gravity, and body alignment. Synergy of muscle work means that there is an appropriate response (speed and strength) of one muscle to another in performing certain motor functions (Munawwarah \& Rahmani, 2015). The synergistic response of the postural muscles to the timing and distance of muscle group activity is needed to maintain balance and posture control. Several muscle groups in both the upper and lower extremities function to maintain posture when standing upright and controlling balance of the body in various movements.

Balance is the ability to maintain the projection of the center of the body on a supporting platform when sitting, standing, walking, and transitting (Howe et al., 2008). Balance on body in various position only will possible if the response of the postural muscles works in synergy as a reaction to changes in position, fulcrum, gravitational force, and body alignment (Perdana, 2014). Muscle strength or is an energy that must be exerted by muscles and some muscle groups that are used for certain activities. Not all have the same muscle strength in carrying out a certain activity which can have a big impact because it is influenced by the stretch, nerve and muscle factors themselves (Pratama, 2019).

Muscle strength can be described as the ability of the muscles to withstand loads either in the form of external loads (external force) or internal force (internal force). Muscle strength is closely related to the neuromuscular system, namely how much the ability of the nervous system to activate muscles to contract. So that the more activated muscle fibers, the greater the strength produced by these muscles. Muscle strength from the legs, knees and hips must be adequate to maintain body balance when there is a force from outside. The muscle strength is directly related to the ability of the muscles to resist gravity and other external loads that continuously affect body position (Perdana, 2014).

Core stability is targeted at the abdominal muscles which connects the pelvic, spine and shoulders, which helps in maintenances of good posture and provides the basis for all arm movements and feet (Akuthota et al., 2007). In core stability activities, it is influenced by superficial (global) and deep (core) muscles that primarily responsible for maintain posture (Irfan, 2010). 
Core stability is an important component to maximize balance efficiency and function in movement upper and lower limb. Core stability is an overview of exercises for the muscles abdominal and pelvic region. The function of core stability exercise can improve balance by increasing the strength of the muscles, especially the muscles of the lumbar spine area. So that the good core stability will stabilizes the segment vertebra then the dynamic limb motion will be more efficient. Postural control dynamics plays a role in functional tasks that are useful for functional movement. Dynamic activity causes COG to move in response to muscular activity. Dynamic control is important in many functions also requires integration of proprioceptive, ROM and power because dynamic balance is important in everyday life and reduce the risk of falls in the elderly

The following are core stabilty techniques for the elderly:

1. Movement on bridge exercise done in a supine sleeping position and with the heels supporting the weight, then the hands are placed on the side or on the body and start lifting the buttocks hold 15-60 seconds. This exercise is intended for strengthening gluteus maximus muscle, hamstring muscle, erector spine and multifidus muscle. This exercise is to increase the core and stabilization of the spine. Maintain the position for 15-60 seconds while maintaining the position.

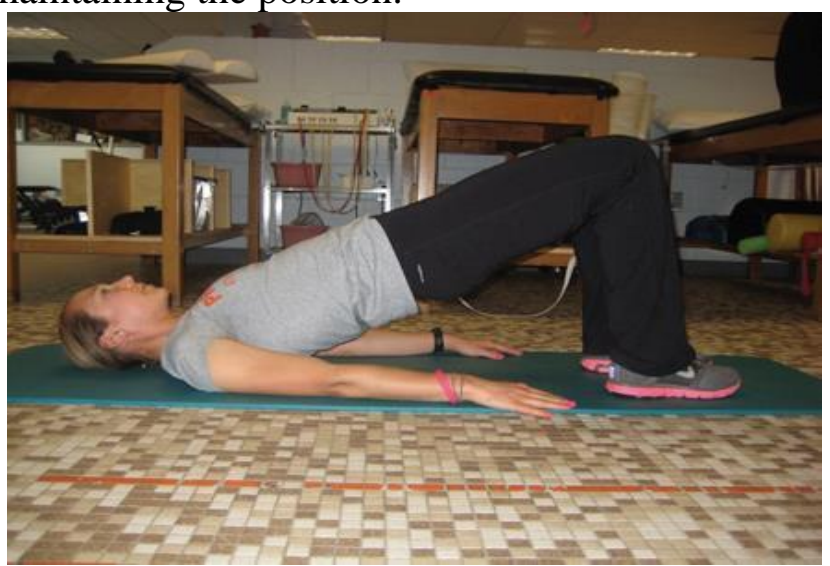

Figure 1. Bridge Exercise

(http://cuhh.soc.srcf.net)

2. Leg lifts is Lie on your back with straight legs relaxed then bend your left leg while your right leg is lifted about 5 inches from the floor, hold for a 3 count and repeat on the opposite side of the leg. Repeat five times on each side. The targets for this exercise are the lower abdominal muscles and pelvis 


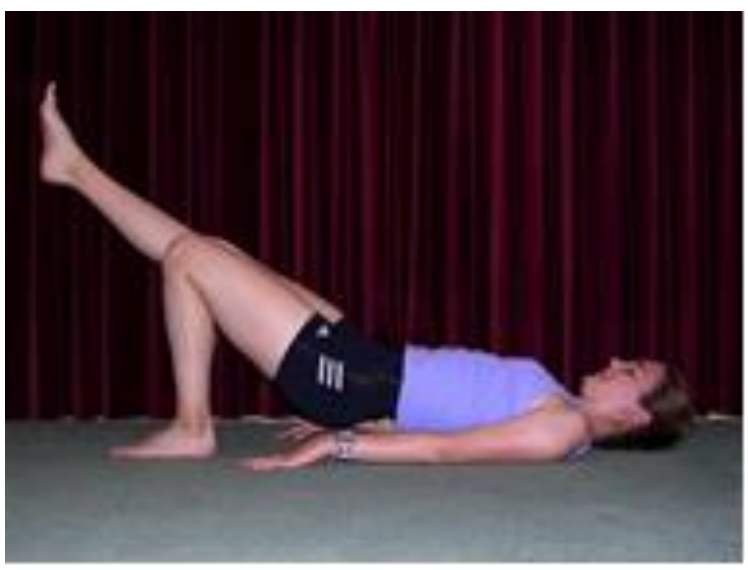

Figure 2. Leg Lift

(http://cuhh.soc.srcf.net)

\section{Hundred Movement}

Hundred Movement is carried out in a supine and sleeping position both legs are lifted up at the same time and begin to bend the knees then start lifting both hands straight hold on 15-60 seconds. This exercise is intended for strengthening abdominal muscles, hands and, erector spine muscle. This exercise is to increase the core and stabilization of the spine. Maintain the position for 15-60 seconds while maintaining the position, so that from this exercise maintaining body posture and reducing the risk of falls in the elderly with balance and postural enhancement exercises is very important for parents, also has an effect on qualitys life, after training core stability ontinued with balance training, with tandem walking exercises.

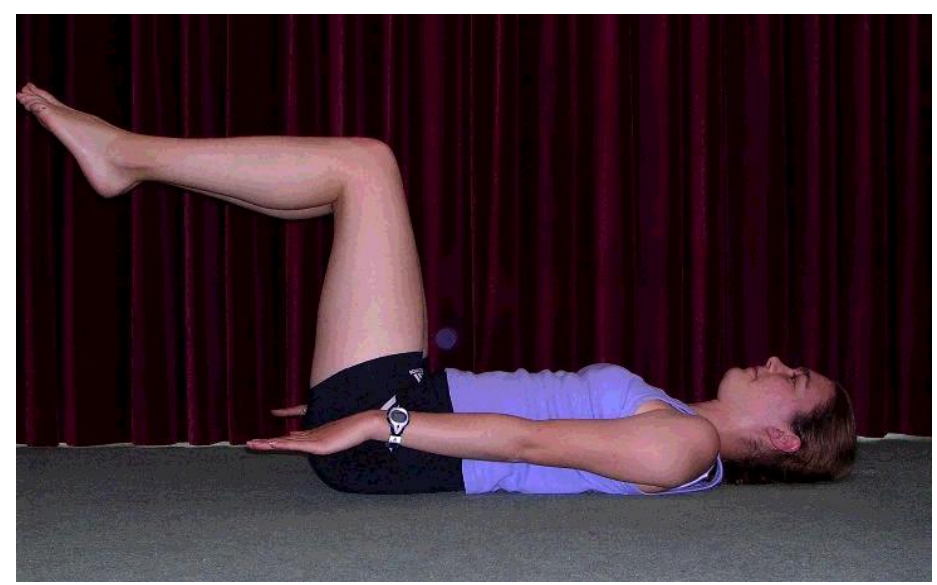

Figure 3. The Hundred Movement (http://cuhh.soc.srcf.net)

Measuring the risk of falling with morse scale is an instrument that can be used to identify the risk assessment of falls in the elderly (Forrest et al., 2012).

Based on the description above, the formulation of the problem posed by the 
International Journal of Health Science and Technology, 3 (1) 2021

Veni Fatmawati, Nova Mega Rukmana, Wibowo Septianto, Diyas Elsa Yuniarsih

researcher is what is the effect of core stability exercise in reducing the risk of falling in the elderly in the Work Area of Kasian 1 Public Health Center?

\section{RESEARCH METHODS}

This type of research is experiment. The research Using a quasy experimental design with pre test and post test group design. Statistic test using Wilcoxon test. Sample of elderly at integrated healthcare center in Ngebel, totaled are 34 elderly. Elderly sample criteria age 60-74 years, do not use assistive devices and do not experience neurological disorders.

\section{RESULTS AND DISCUSSION}

The subjects in this study were the elderly at the Aji Yuswo integrated healthcare center Ngebel, Tamantirto Village, Kasihan District, Bantul Regency, who met the established inclusion and exclusion criteria and were willing to participate in the program until it was completed as many as 34 peoples and none of them experienced drop out. Before and after 4 core stability exercises evaluated by measuring morse fall the scales.

Characteristics of the sample from the results of data collection using the research instrument applied in this study, the value is obtained as the following:

\section{Descriptive Test}

Table.1 Descriptive Sample Data

\begin{tabular}{cc}
\hline & $\begin{array}{c}\text { Group } \\
\text { Characteristics }\end{array}$ \\
\cline { 2 - 2 } & Mean \pm SD \\
\hline Age (th) & $69.76 \pm 4,617$ \\
Weight & $56.06 \pm 5,344$ \\
Height & $156.00 \pm 4,373$ \\
\hline
\end{tabular}

Table 2. Description of Employment Data

\begin{tabular}{|c|c|c|c|}
\hline NO & Profession & Number of people) & $\begin{array}{c}\text { Percentage } \\
(\%)\end{array}$ \\
\hline 1 & Housewife & 22 & $64.71 \%$ \\
\hline 2 & Farmer & 5 & $14.71 \%$ \\
\hline 3 & Labor & 2 & $5.88 \%$ \\
\hline Gender & & Frequency (Person) & Percentage \\
\hline Male & & 13 & $5.9 \%$ \\
\hline woman & & $\begin{array}{l}21 \\
33\end{array}$ & $\begin{array}{l}94.1 \% \\
100 \%\end{array}$ \\
\hline 4 & Teacher & 1 & $2.94 \%$ \\
\hline 5 & Entrepreneur & 4 & $11.76 \%$ \\
\hline
\end{tabular}


Judging from the employment data, the sample is mostly housewives because the sample is mostly women than men, where the majority of elderly women work as housewives. Then followed by the work of farmers where the sample environment is still a lot of rice fields.

Table 3. Treatment Data Description

\begin{tabular}{lcc}
\hline Variable $(\mathrm{n})$ & \multicolumn{3}{c}{ Total Score } \\
& $\begin{array}{c}\text { Before } \\
\text { Mean } \pm \text { SD }\end{array}$ & After \\
& $46.76 \pm 22.357$ & Mean \pm SD \\
\hline Morse fall scale & & $46.18 \pm 22,949$
\end{tabular}

The picture obtained from the distribution of subjects based on age is the lowest age of 60 years and the highest age of the subject is 74 years of age. Every year, $50 \%$ of elderly that living in the institutions experience a fall and many of these people fall several times (Miller, 2007). This study is supported by Kobayashi et al, (2009) which states that elderly women experience falls more than elderly men and some of them experience repeated falls.

The results of the homogeneity test show that the significance value $(\mathrm{p})$ core stability exercise of 0.323 because the significance of $p>0.05$, it can be concluded that the population of dari the same variant or homogeneous. The calculation of the data normality test used the Shapiro-Wilk Test and is said to be normal if $\mathrm{p}>0,05$. Result of the data normality test 0.085 .

The hypothesis Test with willcoxon, because it has a normal data distribution and homogeneous in the group. From the test results obtained with a value of $\mathrm{P}=0.034$, meaning $\mathrm{P}<0,05$ and $\mathrm{Ha}$ accepted and Ho was rejected. So that there is an effect of practicecore stability against the risk of falling in the elderly, this is because Core stability is athe ability to control the position and motion of trunk to pelvic which is used to perform movement optimally, displacement, pressure and motion controlduring activity. Core stability provides a pattern of proximal stability which is used for mobility at the distal. The proximal to distal pattern is a continuous motion that protects the distal sensation used for mobilization while moving. When moving the core muscles cover the trunk and pelvic, this helping in activities, accompanied by energy transfer from large to small bodies during activity (Kibler et al., 2006). The innermost layer of muscles that acts as a stabilizer for body movement, namely tranversus abdominus muscle, multifidus muscle, diaphragm muscle and diaphragm pelvic muscle (Sobotta, 2007). While the outer layer muscles are rektus abdominus muscle, obliqus abdominus eksternus muscle dan obliqus abdominus internus muscle. Tranversus abdominus muscle originates from the inner of rib 6 to the caudal, fascia thoracolumbal, processus tranversus vertebra lumbalis, crista iliaca,1/3 lateral ligamentum inguinal. It muscle is attached to the arcuate line throught the rectus shaft downward joining the tendons in pubic bone. Get innervation from caudal intercostalis nerve and branch from plexus lumbalis, iliohipogastrik, ilioinguinal nerve, 
International Journal of Health Science and Technology, 3 (1) 2021

Veni Fatmawati, Nova Mega Rukmana, Wibowo Septianto, Diyas Elsa Yuniarsih

dan genitofemoralis nerve. The function of this muscle when it contraction will pull and tense the abdominal wall inward (spinal) and cranial.

Core muscle involved among them are quadratus lumborum muscles main function is as a stabilizer during activation of the frontal plane. Activation of quadratus lumborum muscles with a combination of flexion, extension and lateral flexion while supporting the spine in the plane of motion. Pelvic floor muscles and abdominal muscles requires for Upgrade pressure intra abdominal and provide cylinder rigidity to support the trunk, reduce load on the spine muscles and increase trunk stability. Contribution of the diaphragm to pressure intra abdominal important in innervating the movements of the extremities, so that the trunk is stabilized (Hopkins et al., 2009). Abdominal muscles made up of tranversus abdominalis muscle, internal obliques, external obliques and rectus abdominalis. Transverse abdominal muscles contractions increase the pressure intra abdominal and pressure fascia thorakolumbal. The contraction of the abdominal muscles produces a rigid cylinder which increases stiffness (stiffness) of the lumbar spine. Oblique abdominal muscle and rectus abdominalis activating specific patterns by playing an important role in the movement of the lower limbs, as well as providing postural support before the lower limbs move. Therefore, contractions that increase intra-abdominal pressure occur before the initiation of large segment movements in the upper limbs. Spine (core of the body) stabilization occurs before any movements in the limb occur to make the movement members more stable in carrying out movements and muscle activities. In a small part, short muscle like a multifidus muscle provides stabilization of the muscles at a single joint or multiple joint which serves to work more efficiently in controlling spine movement.

Clinically it can be seen that with only a small increase in muscle activation multifidus and abdominal create a spinal segment becomes stiffness. A synergistic activation pattern covering the abdominalis muscle, diaphragma muscle and pelvic floor muscle give base of support throughout trunk and spinalis muscle.In shaping base of support which is also influenced by the combination of the hip and pelvic structures of the two. The hip and pelvic are a combination of large muscles in the area crosssectional. As well as gluteus muscle is a stabilizer of trunk to the base of the foot and provides power for the forward step. Hip or trunk area also contributes about $50 \%$ of the full kinetic energy and force to swing motion the core muscle activation used to produce spine rotation.

\section{CONCLUSION}

Based on the result research and discussion above, it can be concluded that there is effect of core stability exercise in reducing the risk of falling in the elderly.

\section{REFERENCES}

Akuthota, V., Ferreiro A., Moore T., Fredericson M.. (2007). Core Stability Exercise Principles. Current Sports Medicine Reports, 7(1), 39-44. 
Forrest, K. Y. Z., Bunker, C. H., Sheu, Y., Wheeler, V. W., Patrick, A. L., \& Zmuda, J. M. (2012). Patterns and correlates of grip strength change with age in Afro-Caribbean men. Age and Ageing, 41(3), 326-332. https://doi.org/10.1093/ageing/afs030

Http://cuhh.soc.srcf.net. Core Stabilty Technique for the Elderly. Diakses pada 24 Agustus 2015, dari http://cuhh.soc.srcf.net/linksadresources/core-stability.pdf

Hopkins, W. G., Marshall, S. W., Batterham, A. M., \& Hanin, J. (2009). Progressive statistics for studies in sports medicine and exercise science. Medicine and Science in Sports and Exercise, 41(1), 3-12. https://doi.org/10.1249/MSS.0b013e31818cb278

Howe, T., Skelton, D.A., Rochester, L., (2008). Exercise for Improving Balance in Older People.

Irfan, M. (2010). Fisioterapi Bagi Insan Stroke edisi pertama. Yogyakarta: Graha Ilmu, 2252. $58-60$

Kibler, W. B., Press, J., \& Sciascia, A. (2006). The Role of Core Stability in Athletic Function. Sport Medicine, 36(3), 189-198.

Kobayashi, N., Wati, D.N.K., Yamamoto, M., Sugiyama, T., Sugai, Y. (2009). Severity of Dementia as a Risk Factor for Repeat Falls among the institutiolized Elderly in Japan. Nursing and Health Sciences, Vol.11, No.9, 388-396.

Miller, C., A. (2009). Nursing for Wellnesss in Older Adults: Sixth Edition. USA: Wolter Kluwer Health

Munawwarah, M., \& Nindya, P. (2015). Pemberian Latihan Pada Lansia Dapat Meningkatkan Keseimbangan dan Mengurangi Resiko Jatuh Lansia. Jurnal Fisioterapi, 15(April), 38-44.

Munawwarah, M., \& Rahmani, N. A. (2015). Perbedaan four square step exercises dan single leg stand balance exercises dalam meningkatkan keseimbangan berdiri pada lansia 60-74 tahun. Jurnal Fisioterapi, 15(2), 95-105.

Perdana, A. (2014). Stability Terhadap Peningkatan Keseimbangan Pada Mahasiswa Esa Unggul. Jurnal Fisioterapi, 14, 57-68.

Pratama, V. R. (2019). KEKUATAN OTOT TUNGKAI. Jurnal Kesehatan Olahraga, 07(02), 71-78.

Pranarka, Kris (2006). Penerapan Geriatrik Kedokteran Menuju Usia Lanjut yang Sehat. Vol.25, No.4

Putz R. \& R. Pabst. (2007). Atlas Anatomi Manusia Sobotta. EGC: Jakarta. 